\title{
The Role and Problems of Environmental Impact Assessment in Governing Hydro-Power Projects in Cambodia
}

\author{
Han Xia \\ School of Law, University of International Business and Economics, Beijing, China \\ Email: cordeliaxia@163.com
}

How to cite this paper: Xia, H. (2020). The Role and Problems of Environmental Impact Assessment in Governing $\mathrm{Hy}$ dro-Power Projects in Cambodia. Beijing Law Review, 11, 501-518. https://doi.org/10.4236/blr.2020.112031

Received: April 22, 2020

Accepted: May 19, 2020

Published: May 22, 2020

Copyright (c) 2020 by author(s) and Scientific Research Publishing Inc. This work is licensed under the Creative Commons Attribution International License (CC BY 4.0).

http://creativecommons.org/licenses/by/4.0/

\begin{abstract}
Hydro-power projects on the Mekong River may cause great impacts on sustainability of the river. This paper investigates the role of Cambodia's environmental impact assessment (EIA) in governing hydro-power projects and examines whether the current EIA legal regime is capable to address the challenges raised by hydro-power projects. The author finds that Cambodia has established high standards in EIA legal framework. Some proposed requirements, such as the consideration of the impacts of climate change and trans-boundary impacts, may constitute great challenge for future enforcement. Case study in hydro-power projects suggests that the implementation of EIA is far from fulfilling the purposes promised by the black letters in the law. Currently, the main difficulties in implementation are lack of capacity building and public participation. The imperfection of land law as an external element is another obstacle to the effectiveness of EIA law. As a mid-stream riparian state of the Mekong River, on one hand Cambodia is facing potential negative impacts of hydro-power projects in Lao PDR and China, on the other hand, its hydro-power projects may add more threats to the sustainability of Mekong River. This paper argues that for the sustainability of the Mekong water system, Cambodia should implement its EIA law seriously and speed the work of land titles.
\end{abstract}

\section{Keywords}

EIA Legislation and Practices, Land Dispute, Expropriation, Public Participation

\section{Introduction}

Cambodia is a fast growing economy with a relatively poor population for which 
environmental issues accrue. The economic growth has substantial impact on its environment, and in recent years Cambodia is making stride to improve its environmental legal structure, in which the environmental code is the most prominent step. On 7-8 July 2016, the Cambodian Ministry of Environment (MoE) held the second national workshop on the third draft of the environmental code. ${ }^{1}$ The draft brought great expectations ${ }^{2}$ around topics including environmental jurisdictions issues among ministries, public participation in Environmental Impact Assessment (EIA) and environmental offenses and remedies. ${ }^{3}$ While with some prominent movements in legislation, local residents under big projects are often reported as the victims of the rapid economic progress in the country. Hydro-power projects in Cambodia are typical examples of the difficult balance between environment and economic growth.

Focusing on EIA-related issues in Cambodia, this paper consists of four sections with a few suggestions in the conclusion. It starts with the methodology and the factual background in the first section; the second section introduces the basic legal structure of EIA practice in Cambodia; the third section discusses the implementation of EIA in Cambodia's hydro-power sector and possible causes in practice for the troubles as having been criticized in some existed projects; and the last section focuses on loopholes in laws which should be tackled with urgently for the sake of future improvement of hydro-power governance in the country.

\subsection{Methodology}

The methodologies used in this paper include literature review regarding relevant laws and controversial issues about hydro-power projects in Cambodia, and interviews. Through literature review as displayed in the second and fourth sections, the author concludes that the EIA legal mechanism of Cambodia is of high standard, but with problematic loopholes in land legislation and land management. ${ }^{4}$ After field work and interviews related with disputed issues, the author identified some causes for the difficulties in reaching a higher EIA performance, for which political authorities and environmental personnel should bear responsibilities, as will be seen in the third section.

\footnotetext{
${ }^{1}$ The latest available English version is the seventh version draft. See at $<$ http://www.vishnulawgroup.com/attachments/article/60/NR\%20and\%20E\%20Code\%20Draft\%207 \%20(Final)\%2031-DEC-16.pdf> [accessed: 2-05-2020].

${ }^{2}$ While some praised the government's strong commitment in the code, the expected better access to information and ability to participation in decision making, some worry about its future implementation after it is passed and adopted. See at

$<$ http://www.phnompenhpost.com/national/environment-code-due-year $>$ [accessed 30-04-2020].

${ }^{3}$ Minutes of the workshop prepared by Vishnu Law Firm is available at $<$ http://www.vishnulawgroup.com/attachments/article/39/The\%20Report\%20on\%20the\%20Worksh op\%20on\%20the\%20Draft\%20Environmental\%20Code\%207-8\%20Jul\%202016.pdf $>$ [accessed 1-05-2020].

${ }^{4}$ The 2008 Law on Administrative Management of the Capital, Provinces, Municipalities, Districts and Khans, available at

$<$ http://www.cdc-crdb.gov.kh/cdc/twg_network/country_systems_cambodia/strengthening_national systems/documents_for_reform/sndd/organic_law_2008_en.pdf $>$ [accessed 2-05-2020].
} 


\subsection{Factual Background: Impacts of Hyro-Power Dams for Cambodia}

Dams have been promoted as an important means of meeting water and energy needs, and as a long-term, strategic investment with the ability to deliver multiple benefits (WCD, 2001). Up till 2012, about 12 mainstream projects along the lower Mekong river were under consideration (Grumbine et al., 2012). Hydro-power is recognized as an important development opportunity for the Mekong River Basin and the people living within it (MRC, 2015a). In early 2000 's, hydro-power was on the top agenda of all riparian states of the Mekong River (MIME, 2013), and an MRC Strategy on Hydro-power Development which outlined an approach that treats hydro-power potential as one of available renewable natural resources was finalized in 2001 by the Water Resources Management Program of the MRC (MRC, 2002).

With growing knowledge and experience about the performance and consequences of dams, questions have been raised about the returns on the investments required, and the level and distribution of benefits actually delivered (MRC, 2001). Given the awareness about the major challenge for the region causing from the accelerating pace of hydro-power development (MRC, 2010), the Initiative on Sustainable Hydro-power was established in 2008 by the MRC (MRC, 2015b). In the overview of the 2001 report by the World Commission on Dams, it was mentioned that opposition has evolved into a global debate about dams, including about their impact on neighboring communities, livelihoods and ecosystems, and whether they represent the best investment of public funds and resources (WCD, 2001). The environmental NGO International Rivers warned that the construction of large dams on the Upper Mekong had resulted in widely fluctuating river flows, flooding of riverbank gardens, drought and loss of traditional fish, which are likely to lead to lower ecosystem productivity with significant impacts on ecosystems and the communities that depend on the river. The lower Mekong dams will drastically compound these trans-boundary impacts, turning 55 per cent of the lower stretch of the river into a series of reservoirs, blocking critical fish migration and the flow of nutrient-rich sediment necessary to sustain regional agriculture and food security (VNS, 2017).

With an identified high potential of hydro-power development in Cambodia projected at more than $10,000 \mathrm{MW}$, among which $50 \%$ in the Mekong River mainstream, and $40 \%$ in the tributaries of Mekong River (Piseth, 2009), Cambodia faces difficulties in meeting the increasing demand for electricity. The 2004-2007 overview of Cambodia on infrastructure including electricity supply and forecast reported that only $22.47 \%$ of Cambodian households have access to electricity, and the Electricity Department of Cambodia aims to provide electricity service to $100 \%$ of all the villages by 2020 and $70 \%$ of all the rural households by 2030 (CDC, 2011). Up till June 2017 , in the 73 hydro-power dams listed on the website of Open Develop- 
ment Cambodia, ${ }^{5}$ there are 8 operational dams, 33 considered potential sites, 1 under construction, and 31 under study across the country (ODC, 2016). Several of the planned dams may lead to substantial environmental and social costs and impacts due to their location in national parks and wildlife sanctuaries, as well as in areas where upstream and downstream communities are dependent on the rivers and natural resources that will be affected by the dam (Zhang et al., 2014).

\section{EIA Legal Framework of Cambodia: Moving to Higher Standards}

The progress in environmental legislation in Cambodia demonstrates the political will in the country to pursuit environmental protection, which is crucial for the enhancement of EIA procedures. However, high standard of environmental legislation not necessarily always brings good implementation, especially in developing countries (Briffett, 2000) such as Cambodia. The causes for this lack of synchronism between legislation and implementation vary in different countries (Clausen et al., 2010). Currently, the rapid increase in new hydro-power projects and proposals is a dominant issue in the Mekong (Dore et al., 2012). The Donle Sap Lake in Cambodia covers an area considered the heart of the lower Mekong Basin, which creates quite complicated hydraulic and ecological processes in the area (Hoanh et al., 2010). By analyzing the merits and problems in the EIA legal structure and EIA practices in hydro-power projects, the author concludes that the current EIA laws and regulations do not guarantee good quality of EIA and full public participation in project consultations. The general public is vulnerable under large-scale development projects. The interests of affected local residents are not fully protected largely because of the loopholes in the Land Law and Expropriation Law. ${ }^{6}$

As a means to examine, analyze, and assess planed activities (UNEP, 1987; Bates, 2010), EIA is a crucial process in major projects with a view to provide scientific guidance for decision making, and to ensure environmentally sustainable development. While lower Mekong countries are developing with extensive hydro-power infrastructure (Grumbine et al., 2012), EIA is a systematic process for the region to obtain effective examination and evaluation of the environmental effects of proposed activities and to avert possible damage to environment.

\subsection{EIA Legal Framework: Moving Forward}

Cambodia has established an EIA legal framework comprising laws in natural

\footnotetext{
${ }^{5}$ The subset of data on the website of Open Development Cambodia was compiled by International Rivers from various sources, including the Global Reservoir and Dam Database, the Consultative Group on International Agricultural Research Challenge Program on Water and Food - Mekong, and the United States National Inventory of Dams, other government dam inventories, and original data collection by International Rivers.

${ }^{6}$ Cambodia: Law on Expropriation,

<http://ppp.worldbank.org/public-private-partnership/sites/ppp.worldbank.org/files/documents/Ca mbodia_Law-on-Expropriation-\%282010\%29.pdf $>$ [accessed 2-05-2020].
} 
resource management as basis, regulations, and guidelines. Cambodia's EIA legal system is of high standard, including requirements such as consideration of climate change, and protection of the cultural heritages of ethnic minority or indigenous people in the Prakas on General Guidelines for Developing Initial and Full Environment Impact Assessment Reports (Article 4.1.1, Article 4.2). Meanwhile, it is advancing in several aspects, trying to keep pace with international standards, including provisions about strategic environmental assessment, principle of gender equality in the draft Environmental Code (Article 5 Chapter 1 Title 3 Book 1; Article 21 Chapter 3 Title 1 Book 1 in the seventh draft Environmental Code of Cambodia, 2016), and the more detailed procedures for public participation in the proposed guidelines of public participation.

These laudable advances in environmental legislation are good signs, as they demonstrate the awareness of the government and the society to amend some of the blemishes in the EIA system, and protect the environment in a more effective manner.

\subsection{EIA Procedures: Supported by Environmental Laws but with Flaws}

Cambodia has established the legal structure with a comprehensive structure in administration and high standards in EIA, and it is still moving forward in this regard. The high standards for $\mathrm{EIA}^{7}$ were ingrained by the consideration of climate change, the concept of protection for indigenous people in the guidelines, requirements of trans-boundary impact assessment and the principle of gender equality in the draft Environmental Code. Compared with the scant one sentence for public participation in the Sub-decree on Environmental Impact Assessment Process, ${ }^{8}$ the more detailed guidelines on public participation revised on 7 June, 2016, covering definition, related legal aspects, to procedures of participation in each EIA step, signaled one of the new momentum in EIA legislation of Cambodia. ${ }^{9}$

In 1996, Cambodia adopted the Law on Environmental Protection and Natural Resource Management, requiring an assessment on impacts to environment to be made before issuance of decision by the Royal Government on all submitted proposed projects, either private or public (Article 1, Article 6 of Law on Environmental Protection and Natural Resource Management, 1996). In 1999, the

${ }^{7}$ Guidelines that consultants shall follow in conducting EIA include: 2000 Prakas (Declaration) for Conducting EIA Report, the 2009 Prakas for Developing Initial and Full Environmental Impact Assessment Reports, the 2000 Prakas for Determination of Service Charge for EIA Report Review and Follow-up and Monitoring of Project Implementation, the 2014 Prakas on Registration of Consulting Firms for Studying and Preparing ESIA Report, and the 2014 Prakas on Establishment of the Technical Working Group for Reviewing and Commenting on the EIA Report.

${ }^{8}$ The Prakas on Public Participation in Environmental Impact Assessment Process is available at $<$ http://www.vishnulawgroup.com/attachments/article/61/Prakas\%20on\%20Public\%20Participation \%20Guideline\%20Eng.pdf $>$ [accessed 2-05-2020].

${ }^{9}$ The Draft Guidelines on Public Participation in Environmental Impact Assessment Process is available at

$<$ http://www.vishnulawgroup.com/attachments/article/62/Public\%20Participation\%20Guideline\%20 Eng.pdf $>$ [accessed 2-05-2020]. 
Sub-decree on Environmental Impact Assessment Process was passed, which laid out a cooperative mechanism in EIA administration among central and local environmental officials and with other ministries (Article 3, Article 4, Article 5 of Sub-decree on Environmental Impact Assessment Process, 1999). Despite the overall clear responsibility distribution among environmental officials in the sub-decree, the EIA administration is not satisfactory in reality. As illustrated with more details in next section of this paper, the low responsibility requirement (Article 18 of Sub-decree on Environmental Impact Assessment Process, 1999) and the disappointing regulation implementation are the sticking points in EIA. Stricter performance requirements, greater clarification and understanding of each stakeholder's role (Saunder \& Bailey, 2009) in EIA are the ways to move forward.

The 1999 Sub-decree requires all existing project owner or responsible person compile initial EIA report and submit it to the MoE for a review at least within a year of the promulgation of the sub-decree (Article 21 of Sub-decree on Environmental Impact Assessment Process, 1999). However, given the situation that about $80 \%$ of the 100 or more on-going projects ${ }^{10}$ still have not submitted EIA reports to MoE, the administrative decentralization might be a solution (Brandon \& Ramankutty, 1993; Niazi, 2011; Serey, 2007; Batterbury \& Fernando, 2005).

While environmental legislation is a strong priority of the Hun Sun government (Amaro, 2016; Bunthoeun \& Kimthach, 2016), the effectiveness of EIA is impaired by the low requirements on the performance of officials in report reviewing and the unchecked situations of existing projects in environmental assessment. The new requirements for trans-boundary impact assessment, strategic environmental impact assessment and consideration of climate change in environmental management laid out in the draft Environmental Code might face challenges in future enforcement. The other two pieces of laws, although do not directly regulate EIA are constraining the improvement of EIA practices in the country, the Land Law and the Expropriation Law, will be discussed in the third section.

\section{Implementation of EIA in Hyro-Power Projects in Cambodia}

Despite the laudable administration distribution laid out in legislation and guiding documents, the implementation of EIA in Cambodia is far from satisfactory. Many cases happened in Cambodia related to public welfare and social well-beings have caused great attention among international societies. Apart from loopholes in the legal framework which will be discussed separately in the fourth section due to its length, intervention of political authorities, poor performance of EIA personnel and lack of public participation during consultation are the most often heard criticisms from media, locals and environmentalists in ${ }^{10}$ Lack of EIA report submitting among on-going projects is a hard reality that environmental officials are frank about. The director of EIA Department mentioned in an interview that currently among the over 100 projects that were entitled to submit EIA reports, about $20 \%$ have done so as required. Seventeen years have passed since the adoption of the 1999 EIA sub-decree, the majority of project owners are acting against the sub-decree, and violating the law. 
the country.

\subsection{Political Decision Making in Hydro-Power Projects}

The rate of public participation in hydro-power projects of Cambodia were low, what's worse, the no process of public participation did happen in some cases. In the Kamchay Project, ${ }^{11}$ environment assessment and information disclosure about projects came late (Grimsditch, 2012). In the Lower Sesan Dam Project, the serious negative environmental and social impacts of projects haven't been mitigated or dealt with properly (Baird, 2009; NGOF, 2015). The Cheay Areng Dam in the Areng Vally is anticipated with serious social and environmental ramifications. It was criticized for its vested political interests, high capital inputs but low return, and with a concomitant risk of potential political instability (Yeophantong, 2016).

\subsection{Environmental Personnel Lack of Capacity}

EIA consultants and environmental authorities are the two actors that substantially influence the quality of EIA apart from project owners. The poor performance of environmental personnel exists widely in the scoping, assessment, review, and monitoring of projects' environmental impacts in all sectors, which incites detrimental negative impacts in hydro-power project assessments.

The substantive performance of EIA system is defined as the extent to which the EIA process contributes to the EIA objectives: environmental protection or the sustainable development (Kolhoff et al., 2015). EIA consultants have a strong position for guiding the quality of the environmental assessment, partly due to the key knowledge they hold, and partly due to their early involvement in making strategic decisions on what issues and impacts to include in the EIA profile and how they should be addressed (Kagstromin, 2016).

The Environment Department of World Bank concluded in a 1997 report that use of local consultants was particular common in China and some other East Asian countries, as well as Brazil and India (Environment Department of World Bank, 1997). It estimated that in water supply, sanitation and sewerage projects in Asia during the 1990 's, local consultants carried out $70 \%$ of the environmental assessments (Environment Department of World Bank, 1997). The report perceived that occasionally local consultant teams did not have enough experience in EIA analysis and reporting, and were biased to ecological or social concerns (Environment Department of World Bank, 1997). In the case of Cambodia, only the registered 13 Cambodian firms are allowed to conduct environmental assessment. During the research period, local consultants complained about problems they have in understaffing and insufficiency in technical equipment.

As it is required in the consultation and communication with local communi-

${ }^{11}$ The brief information about the Kamchay Hydro-power project in the EXCEL titled "List of EIAs received by NGOF 12 September 2013", which can be downloaded at

$<$ http://www.ngoforum.org.kh/index.php/en/library/useful-documents $>$ [accessed 2-05-2020]. 
ties, project owners and government officials, environmental consulting firms should hire sufficient and qualified employees with knowledge in the specific areas correspond to the companies' registered lines of business. The back-and-forth consulting and compiling process during EIA report preparation requires strong capabilities in different areas, depending on the firm's sphere of business.

It takes considerable political will and administrative drive to implement environmental provisions, and the political commitment to protecting the environment is increasing in Cambodia. What is the weakest in government institutions are regulation enforcement and environmental impact monitoring (Brandon, 1993). In Cambodia, it is specifically about the low responsibility requirement and the sometimes disappointing regulation implementation.

Unfortunately, the responsibility requirement is low for environmental officials in terms of reviewing EIA report. Article 18 of the 1999 EIA Sub-decree has raised eye-brows since the sub-decree was passed and entered into force. It provides that if the MoE fails to respond its finding and recommendations back to project owner and to project approval ministry or institution within 30 working days (commencing from the date of registration of their initial EIA report and pre-feasibility study report), the approval ministry or institution will assume that the revised Initial Environmental Impact Assessment (IEIA) report has complied with the criteria of the sub-decree (Article 18 of Sub-decree on Environmental Impact Assessment, 1999). This provision is disturbing, as it allows for groundless assumptions to be made by authorities when no respond and recommendation was received, whatever the reason for such lack of feedback. It offers a "back door" for MoE to get away from the charge of dereliction, as no one can eliminate the possibility of duty negligence from MoE officials under such a provision.

\subsection{Lack of Public Participation in Consultation}

Public participation has been regarded as one of the crucial steps in environmental protection to eliminate negative side effects causing to affected local people. Disparity of information exists between the investor and those likely to be affected by a project. Without the public understanding the basic nature of the proposed project or key terminology being used, there will be no effective dialogue with the local community. Engaging with stakeholders up front reduces the likelihood of misunderstandings during the consultation stage and ultimately leads to more efficient and effective consultations (Karol \& Neyman, 2015).

In Cambodia, awareness of public participation in environment issues has been enhanced in recent years. It has been promoted partly due to the requirements of some international project fund providers at the early stage of project application. In a statement released in August 2016, USAID announced that it is seeking public comments before pumping $\$ 10$ million to $\$ 25$ million into projects to promote the responsible land management and sustainable development of the protected area in Prey Lang (Maza \& Sengkong, 2016). However, the overall rate of public participation in development project remains low in Cam- 
bodia. Causes for the situation cannot be exhausted in this paper. But based on the author's research in Cambodia during the summer of 2016, there are at least the following causes: no effective way for the public to obtain project information; officials' reluctance to provide project-related information to the public; lack of opportunity or awareness among locals to participate in public consultation; and women limited by social biases to participate. ${ }^{12}$

As of 2019, the openly accessible website for project-related documents, IEE (Initial Environmental Examination) or EIA reports by project participants has not been seen in most cases. Despite the fact that MoE has the responsibility to provide project-related information when required, the attitude of officials about providing information is quite often seen as reluctant. Some officials mentioned during interview that the MoE did not have such responsibility; some mentioned that an official letter and purpose for requiring the information should be submitted to department director in order to obtain documents and figures officially. Not to mention the time-consuming and low possibility of feed-back, it can be expected that few local people may have the willingness to try the hard process to require the documents, which they would probably find difficult to understand.

While the goal of awareness-raising is to fill the information gap between the project owners and anyone potentially affected by the project and improve transparency, the purpose of consultation is to gather the concerns and desires of stakeholders who will be affected by the project and to align expectations of all parties (Karol, 2015). With an investment amounted to \$ 280 million (Hydroworld, 2011), the Kamchay Hydro-power Dam was located in the Bokor National Park of Kampot Province (Grimsditch, 2012). The project has bad reputations among local societies in Cambodia, to a large extent caused by the strikingly lack of public participation before and during the construction.

The latest available EIA report on Kamchay project is an SEIA (Strategic Environmental Impact Assessment) report approved in April 2011. ${ }^{13}$ However, based on the information from a local non-government organization, NGO Forum on Cambodia, the full EIA on the project was passed in May 2011. As the final version is not available to the public, it remains unknown whether the two versions are identical. During the process of conducting EIA, the projector had very few communications with the affected communities. The first time local authorities discussed the project openly with local people was in late 2007, at the end of a public meeting on a malaria awareness held by a local NGO (Grimsditch, 2012). The only plan that villagers interviewed had ever seen was posted on a public notice board close to the site, and a brief description of the project alongside a picture of the completed dam and surrounding areas (Grimsditch,

${ }^{12}$ According to interviews with an MoE officials on 20 July, 2016, an EIA Reviewing Committee member on 24 July, 2016, and lecturers on EIA in the University of Phnom Penh on 21 July, 2016, and EIA consultants on 23 August and 9 September 2016.

${ }^{13}$ The SEIA report is available and can be borrowed for research at the NGOF Cambodia, a NGO based in Phnom Penh which conducts policy analysis, monitoring and advocacy on a variety of social issues. 
2012).

It should also be noted that there is an information disparity between villagers and local authorities. According to the available ESIA report, SAWAC, the consultants company in charge of the EIA writing had hold meetings and interviews in 2010 with 233 participators. 18 of them were local authorities from Kampot and 215 were "concerned people" living in the area (Gatke \& Borin, 2013).

Conducting the IEIA in October 2006, the consultants company organized a public consultation in Kampot province to discuss with the public about the content of the IEIA report (Grimsditch, 2012). However, the participants were mainly government officials. One international organization was known to have been invited to the consultation, and no affected people or local organizations were invited. When a local NGO coalition later questioned about the reason why no other organizations were invited and the reason for the low representation rate of local groups, the reply they received was that no more space available in the meeting room. While the villager and civil society members could submit comments, they did get access to review the EIA document before the meeting. Comparatively, the information to community member was very limited, and they also got less opportunity to provide comments or raise concerns about the project (Grimsditch, 2012).

When it comes to public participation for female in Cambodia, they are less used to appear in public activities, still less in posing questions to authorities. While the reasons behind can be multi-facet, the impact of the male dominated tradition in family, social and political issues for sure is one of them. Secondly, the legal system fails to provide equal rights for women in society, with the land law as an outstanding example, which describes that female offspring do not have the right to inherit lands in a family. In addition, women are sometimes treated unequally compared with their male counterparts in administration and social management, which means that the rights of equal participation and compensation poorly ensured, and voice and opinions from women less taken by administrative authorities and officials. To make it worse, female has fewer opportunities in the job market and more dependency on the local environment for existence. These factors make them more vulnerable to the radical environmental and social impacts that large scale development projects might bring forth to local communities.

\section{Imperfect Land Law and Expropriation Law Exasperate Illegal Evacuations}

Local residents are often reported in recent years as the victims of the rapid development in the country. At all levels of environmental planning and management, management of natural resources is the cornerstone for the peace and security of a society. Land Law and Expropriation Law have the utmost impact on EIA in Cambodia. As is discussed in this section, the flaws in land and expropriation laws no doubt are to be blamed for the difficulties in EIA implementation, and should be amended through legislative procedures. 


\subsection{Land Disputes in Cambodia}

Currently, lots of development projects in Cambodia had land conflicts with local people. A report by the international NGO LICADHO estimated that in the 13 provinces it has offices, over 250,000 Cambodians, roughly half of the country, have been affected by land disputes since 2003 (LICADHO, 2009). Various human rights organizations, both local and international, and United Nations bodies reported that forced evictions, land-grabbing and other violations of the Land Law continue to exacerbate the hardships faced by vulnerable families (Amnesty International, 2008; Barton, 2008). In 2007, UNDP Cambodia revealed that there are signs that the number of land disputes is increasing. Both the formal court system and the non-governmental organizations monitoring the land sector report showed an increase in land disputes since the late 1990s (Supreme National Economic Council, 2007). Between 1998 and 2003, the Phnom Penh municipality forcibly evicted 11,000 families (Mgbako, Gao, \& Joynes, 2010). According to local NGO Sahmakum Teang Tnaut, in the Capital City Phnom Penh alone, at least 29,700 Cambodian families have been displaced from their homes since 1990 (STT, 2014). Conservative estimates suggest that at least 150,000 imminent threat of forced eviction, including approximately 70,000 in Phnom Penh (Grimsditch \& Henderson, 2009).

The land law and policies are not constructed in a way protecting the affected communities that are most vulnerable to displacement in the country. The Constitution and the 2001 Land Law prescribes that Cambodian individuals have the right to ownership. Limitation of such right would be allowed only when it is in the public interest and with appropriate and just compensation (Article 44 Constitution of the Kingdom of Cambodia; Article 4 and Article 5 of the 2001 Land Law). Yet violent, forced evictions that occur without proper compensation have become the norm in Cambodia (Mgbako, Gao, \& Joynes, 2010). A key argument held by the government has been that many of those affected have been illegal squatters, living on state public land. However, land title conflict is resulted partly from the historical change of land policy after Kmer Rouge period. It is imperative for the government to finish the task of assessing whether or not the occupants have rights to the land as legal possessors. There should have been quicker land title assessment programs around the country after the stipulation of the 2001 Land Law.

To better understand how the large scale illegal possessions came about, and how families currently with no legitimate residential land title are less protected by law, the following part of this section outlines the historical changes in land law, the fissures in it and in the Expropriation Law that might lead to rights encroachment to local residents.

\subsection{Land Law}

The 2001 Land Law can be seen as a development from the 1992 Land Law. It was made to adapt to social changes, and for the consistency between land law 
and the 1989 Constitution of Cambodia (Rendall, 2003). To have a better grip of the picture, an appendix with comparison on subject headings in the 1992 and 2001 Land Laws is added.

In the colonial and pre-colonial times, land titles did not have a huge importance in Cambodia, as there was enough land for residents then. During the Khmer Rouge period from 1975 to 1979, all land ownership was dissolved and land titles destroyed (Rendall, 2003). After the year 1979, people began to slowly return to their homeland, and re-populate the cities. In 1992, Cambodia adopted its first full land law, which set out the means by which ownership could be acquired: succession, contract, or by converting "temporary possession" into full ownership (Article 59 of Land Law, 1992). In 2001, a new Land Law was adopted, and a foundation was provided for a national land register and land registration program (Lindstrom, 2013), which is a hard on-going process in Cambodia. The new law does not stand firmly for human rights protection for at least two reasons. First, although the 2001 Land Law confirmed that legal possession can be transferred to full legal ownership, it is not possible to commence legal possession after the law was passed (Article 39 of Land Law, 1992). It means any land upon which occupants commenced possession after 31 August 2001 should be considered state land. Second, instead the right to receive title, the 2001 Land Law only gives legal possessors the right to apply for title (Article 30 of Land Law, 1992). The conditions are set out in Article 39 (Article 39 of Land Law, 1992) as follow,

"Anyone claiming legal possession must be able to prove that their possession began before the Land Law was passed, and that they meet five further conditions. All possession must be: unambiguous, non-violent, non-notorious to the public, in good faith, and possession of state public property or someone else's private land is illega?'.

If a possessor meets the requirements listed above, applies for title or is in an area where the national systematic titling program is being conducted, the only ground for denying title is when there is a conflicting claim to the land.

In 2008, a study found that 21 percent of households were landless in Cambodia, and further 45 percent owned less than 1 hectare of land (Chan, 2008). In August 2016, the spokesman of Cambodia's Ministry of Land Management trumpeted on Radio France International a ninety percent dip in the number of registered land disputes in Cambodia. While the figure cannot be clarified, the deputy director of advocacy at rights group LICADHO said that the figure from her NGO suggested that there has been no slowdown in the emergence of new land disputes. A key challenge remains in implementing a well-developed land policy or law with a state mapping system of land ownership.

\subsection{Expropriation Law}

As for land compensation, according to Cambodia's 1993 Constitution and 2001

Land Law, the State is entitled to expropriate private owned property in the pub- 
lic interest and with the payment of fair and just compensation in advance (Article 44 of Constitution of the Kingdom of Cambodia, 1993; Article 4, 5 of Land Law, 2001). Under this backdrop, the 2010 Expropriation Law stipulates that private property is to be compensated based on market price (Article 22 of Law on Expropriation, 2010). However, it only extends protections to legal and rightful owners of land, which means that people that were not given authorization to occupy or use land are not entitled to any indemnity for any work and improvement carried out on the property. In the absence of a domestic legal framework which can provide guidance in dealing with the so-called illegal occupation, the rights prescribed in international human rights law for housing and subsistence for these vulnerable families are largely unprotected.

The Law on Expropriation sets out the conditions and procedures under which legitimate owners and possessors may be legally deprived of their land if it is required for a public interest project. Moreover, there are conditions set out, stating that expropriation can be carried out by the government only for public physical infrastructure. In addition, the law brought forth ideas of publicly conducted survey by a to-be-established Expropriation Committee (Article 5, 7, 12, 13, 15, 16 of Law on Expropriation, 2010) with detailed descriptions about the owner and/ or rightful owner of the real estate and other properties which might need for compensation. It stipulates that the Expropriation Committee shall conduct a detailed interview with all concerned parties about the issues of immovable property affected by the public physical infrastructure project. Within 30 working days after completing the survey, the Committee shall provide a report with recommendations and propose for the government's approval.

More importantly, the Expropriation Committee shall determine the fair and just compensation; set a deadline for complaint; send the declaration accompanying a copy of the Expropriation Law to all owners and/ or rightful owners; disseminate the declaration via media; post the declaration at relevant commune offices where the public physical infrastructure is going to take place (Article 19 of Law on Expropriation, 2010).

From the detailed description in the law about the responsibility of the Expropriation Committee, we can see clearly the vital role the organ play in land management and compensation issues. However, with no guidance or official document to check the procedures and amounts for compensation, we cannot say that there is enough legal basis to justify the expropriation conducts as a result of public projects. In Cambodia, while interests of residents with no legitimate land title might fall under the threat from large scale projects, more transparency and stronger legality for procedures are needed.

As illustrated above, what may need amendments for EIA in Cambodia are two keystone statutes in resource management: the land law and expropriation law. Meanwhile, more and area-specific guidelines with unified version used by all project owners will greatly stimulate the efficiency and credibility of EIA report compiled by consultants. 


\section{Conclusion}

With an increasingly extensive legal structure and high standards in EIA, Cambodia's EIA regime is now more or less in a "mid-age crisis". EIA framework can be a rein on the dashing horse of economic development (Bian, 2018). However, it is extremely difficult for Cambodia to accomplish the designed objectives of EIA as it is confronted with the difficulties in human resources, law implementation and public participation in EIA practices. Higher standards do not solve many of the difficulties it is confronted with, and the root causes for the vulnerability of the public facing big projects remain outstanding in the land sector.

The sharp contrast between Cambodia's high EIA standards and its poor implementation is a typical example among developing countries, showing alarmingly that the rule of law in EIA is systematic and probably difficult to achieve fast, even when with some promising mechanisms established in paper.

The loopholes in the Land Law and Expropriation Law are hazardous for the stability of the society and the well-beings of the public in the scenario of Cambodia. The author is of the view that improvement should first come from the upstream legal framework. For this purpose, the Cambodian legislative branch might need to amend the Expropriation Law in the following years and the government should steadfastly carry out national land title registering and mapping. At the same time, evictions should be avoided whenever possible and in cases in which they are unavoidable, proper compensation and resettlement options must be offered to affected persons in order to ensure that, at a minimum, their living standards are maintained (Bugalski \& Medallo, 2012). As the Government of Cambodia has ratified all the major international human rights covenants and as such is legally bound by their provisions. During the planning and implementation of any settlement ensued after project development, the government is required to respect, protect and fulfill the right of every citizen to adequate housing embedded in the International Covenant on Economic, Social and Cultural Rights. ${ }^{14}$

\section{Acknowledgements}

This paper was written as a research report after the author's three-month stay in Cambodia, thanks to the enormous help and valuable comments from Professor Yongmin Bian of University of International Business and Economics and Mr. Ali Al-Nasani of Heinrich Boll Stiftung. The author is grateful to the anonymous comments from BLR reviewer. All errors remain mine.

\section{Conflicts of Interest}

The author declares no conflicts of interest regarding the publication of this paper.

${ }^{14}$ Article 11.1, ICESCR: The States Parties to the present Covenant recognize the right of everyone to an adequate standard of living for himself and his family, including adequate food, clothing and housing, and to the continuous improvement of living conditions. The States Parties will take appropriate steps to ensure the realization of this right, recognizing to this effect the essential importance of international co-operation based on free consent. 


\section{References}

Amaro, Y. (2016). Environment Code Due This Year. Phnom Penh Post. http://www.phnompenhpost.com/national/environment-code-due-year

Amnesty International (2008). Rights Razed-Forced Evictions in Cambodia (pp. 6-8). London: Amnesty International.

Baird, I. G. (2009). Best Practice in Compensation and Resettlement for Large Dams: The Case of the Planned Lower Sesan 2 Hydropower Project in Northeastern Cambodia. Phnom Penh: Rivers Coalition in Cambodia.

Barton, C. (2008). Forced Evictions on the Rise Despite Condemnation. Phnom Penh Post.

http://www.phnompenhpost.com/national/forced-evictions-rise-despite-condemnation

Bates, G. (2010). Environmental Law in Australia (7th ed.). Australia: Lexis Nexis Butterworths.

Batterbury, S. P. J., \& Fernando, J. L. (2005). Rescaling Governance and the Impacts of Political and Environmental Decentralization: An Introduction. World Development, 1853, 1851-1863. https://doi.org/10.1016/j.eiar.2009.01.006

Bian, Y. (2018). The Role of Environmental Impact Assessment in the Governance of Nu-Salween River: A Comparative Study of Chinese and Myanmar Approaches. In Y. Zhao (Ed.), International Governance and the Rule of Law in China under the Belt and Road Initiative (pp. 218-242). Cambridge: Cambridge University Press.

Brandon, C., \& Ramankutty, R. (1993). A Summary of a World Bank Decision Paper, Toward an Environmental Strategy for Asia (Vol. 8, pp. 1-28). Washington DC: International Bank for Reconstruction. https://doi.org/10.1596/0-8213-2737-2

Briffett, C. (2000). Environmental Impact Assessment in Southeast Asia: Fact and Fiction? GeoJournal, 333, 333-339.

Bugalski, N., \& Medallo, J. (2012). Derailed: A Study on the Resettlement Process and Impacts of the Rehabilitation of the Cambodian Railway (Vol. 7, pp. 1-98). Phnom Penh: Bridges across Borders Cambodia.

Bunthoeun, O., \& Kimthach, S. (2016). Report on Second National Workshop on the Draft of Environmental Code of Cambodia (Vol. 2-3, pp. 1-28). Phnom Penh: Vishnu Law Firm.

CDC (2011). Investor's Information: Infrastructure-General Situation of Electricity Supply. Council for the Development of Cambodia.

http://www.cambodiainvestment.gov.kh/investors-information/infrastructure/electricit y.html

Chan, S. (2008). Impact of High Food Price in Cambodia. Policy Brief, Phnom Penh: CDRI.

Clausen, A., Vu, H. H., \& Pedrono, M. (2010). An Evaluation of the Environmental Impact Assessment System in Vietnam: The Gap between Theory and Practice. Environmental Impact Assessment Review, 136, 136-143.

https://doi.org/10.1016/j.eiar.2010.04.008

Dore, J., Lebel, L., \& Molle, F. (2012). A Framework for Analyzing Trans-Boundary Water Governance Complexes Illustrated in the Mekong Region. Journal of Hydrology, 28, 23-36. https://doi.org/10.1016/j.jhydrol.2012.07.023

Environment Department of World Bank (1997). The Impact of Environment Assessment, A Review of World Bank Experience (pp. 1-176). World Bank Technical Paper No. 363, 33, 42, 43. Washington DC: International Bank for Reconstruction. https://doi.org/10.1596/0-8213-3923-0 
Gatke, P., \& Borin, U. (2013). The Kamchay Hydropower Dam: An Assessment of the Dam's Impacts on Local Communities and the Environment (pp. 1-104). Phnom Penh: NGO Forum Cambodia.

Grimsditch, M. (2012). China's Investments in Hydropower in the Mekong Region: The Kamchay Hydropower Dam, Kampot, Cambodia (pp. 1-60). Washington DC: World Resources Institute.

Grimsditch, M., \& Henderson, N. (2009). Untitled: Tenure Insecurity and Inequality in the Cambodian Land Sector (Vol. 33, pp. 1-102). Centre on Housing Rights and Eviction, Phnom Penh: Jusuit Refugee Service.

Grumbine, R. E., Dore, J., \& Xu, J. (2012). Mekong Hydropower: Drivers of Change and Governance Challenges. Frontiers in Ecology and the Environment, 10, 91-98. https://esajournals.onlinelibrary.wiley.com/doi/epdf/10.1890/110146

Hoanh, C. T., Jirayoot, K., Lacombe, G., \& Srinetr, V. (2010). Impacts of Climate Change and Development on Mekong Flow Regime. First Assessment-2009 (pp. 1-105). MRC Technical Paper No. 29. Vientiane, Lao PDR: Mekong River Commission.

Hydroworld (2011). Cambodia Inaugurates 193-MW Kamchay Hydropower Project. Hydroworld.

http://www.hydroworld.com/articles/2011/12/cambodia-inaugurates.html

Kagstromin, M. (2016). Between "Best" and "Good Enough": How Consultants Guide Quality in Environmental Assessment. Environmental Impact Assessment Review, 169, 169-175. https://doi.org/10.1016/j.eiar.2016.05.003

Karol, C., \& Neyman, Y. (2015). Operational Guidelines for Responsible Land-Based Investment (pp. 1-70). Washington DC: USAID.

Kolhoff, A. J., Runhaar, H. A. C. et al. (2015). The Influence of Actor Capacities on EIA System Performance in Low and Middle Income Countries-Cases from Georgia and Ghana. Environmental Impact Assessment Review, 167, 167-177.

https://doi.org/10.1016/j.eiar.2015.11.011

LICADHO (2009). Land Grabbing and Poverty in Cambodia: The Myth of Development (pp. 1-36). LICADHO: Phnom Penh.

Lindstrom N. (2013). Policy for the Poor? Phnom Penh, Tenure Security and Circular (pp. 1-88). Phnom Penh: Heinrich Boell Foundation.

Maza, C., \& Sengkong, B. (2016). USAID to Consult Public before Next Round of Prey Lang Funding. Phnom Penh Post.

http://www.phnompenhpost.com/national/usaid-consult-public-next-round-prey-lang -funding

Mgbako, C., Gao, R. E., \& Joynes, E. (2010). Forced Eviction and Resettlement in Cambodia: Case Studies from Phnom Penh. Washington University Global Studies Law Review, 9, 39-76.

MIME (2013). National Sector Review: Hydropower. Phnom Penh: Ministry of Industry, Mines and Energy (MIME).

MRC (2001). Annual Report 2001. Cambodia, Lao PDR, Thailand, Viet Nam: Mekong River Commission (MRC).

MRC (2010). Annual Report 2010. Mekong River Commission (MRC): Cambodia, Lao PDR, Thailand, Viet Nam.

MRC (2015a). The ISH 0306 Study: Development of Guidelines for Hydropower Environmental Impact Mitigation and Risk Management in the Lower Mekong Mainstream and Tributaries. Vientiane, Phnom Penh: Mekong River Commission (MRC).

MRC (2015b). Initiative on Sustainable Hydropower (pp. 1-88). Mekong River Commis- 
sion.

http://www.mrcmekong.org/about-mrc/completion-of-strategic-cycle-2011-2015/initia tive-on-sustainable-hydropower/

NGOF (2015). Survey: The Compensation Policies and Market Property Price: Lower Sesan 2 Dam Development Project. Phnom Penh: NGO Forum on Cambodia (NGOF).

Niazi, T. H. (2011). Decentralization and Decentralization Reforms in Cambodia Recommendations for an Institutional Framework (pp. 1-164).

ODC (2016). Hydropower Dams. Open Development Cambodia. https://opendevelopmentcambodia.net/profiles/hydropower-dams/

Piseth, C. (2009). National Power and Hydropower Development Plans in Cambodia. Phnom Penh: Ministry of Industry, Mines and Energy (MIME).

Rendall, M. (2003). Land Law of Cambodia: A Study and Research Manual.

Saunder A. M., \& Bailey, M. (2009). Appraising the Role of Relationships between Regulators and Consultants for Effective EIA. Environmental Impact Assessment Review, 284, 284-294.

Serey, S. (2007). Impediment to Community Fisheries Management: Some Findings in Kompong Pou Commune, Krakor District in Cambodia's Tonle Sap. Singapore Journal of Tropical Geography, 399, 398-413.

STT (2014). Facts and Figures: Phnom Penh's History of Displacement-Evicted Communities from 1990 to 2014 (pp. 1-14). Phnom Penh: Sahmakum Teang Tnaut (STT).

Supreme National Economic Council of Cambodia (2007). The Report of Land and Human Development in Cambodia (pp. 1-32). Phnom Penh: Supreme National Economic Council. https://doi.org/10.1016/j.worlddev.2005.11.019

UNEP-United Nations Environmental Programme (1987). Goals and Principles of Environmental Impact Assessment. Preliminary Note, Issued on January 16, 1987. https://www.elaw.org/system/files/unep.EIA_.guidelines.and_.principles.pdf

VNS (2017). Vietnam Urges Laos to Rethink Mekong River Dams. Mekong Eye News Digest.

https://www.mekongeye.com/2017/05/17/vietnam-urges-laos-to-rethink-mekong-river -dams/

WCD (2001). Dam and Development: A New Framework for Decision Making. Nairobi: Word Commission on Dam (WCD).

Yeophantong, P. (2016). China's Dam Policy in the Mekong Region: Three Game Changers. In D. Blake, \& L. Robins (Eds.), Dynamics of Water Governance in the Mekong Region (Vol. 127, pp. 124-146). Strategic Information and Research Development Center Press.

Zhang, W., Mekonnen, D., Ringler, C., Kura, Y., Samonn, M., Bunnarith, T., Gatke, P., \& Bhandary, P. (2014). Water Resource Uses and Potential Impact of Hydropower Development: Case Study from Northeast Cambodia (pp. 1-47). Washington DC, Phnom Penh: International Food Policy Research Institute, World Fish Center, Culture and Environment Preservation Association. 


\section{Appendix}

Comparison of the tables of the 1992 and 2001 Land Laws.

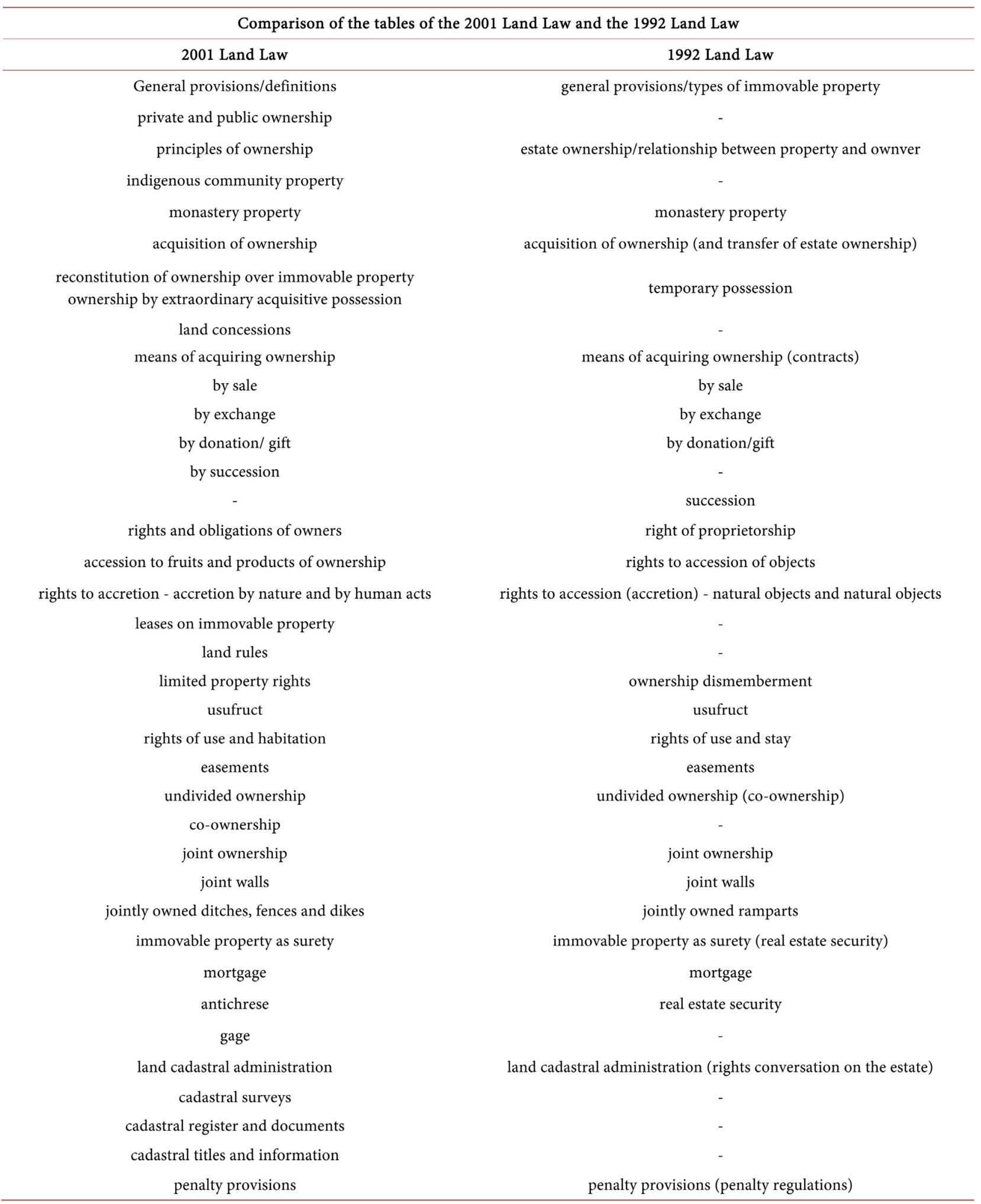

Note: While most titles of provisions are equivalent, “-” signals difference and it means the relevant provision of such a title is lacking. 